few months, and was treated with tonics and belladonna, and she improved to a certain extent. She returned again in November, and I made the following further notes about her condition :-Complexion muddy, and skin of face and neck rather greasy and brown, being specially pigmented about the eyes. Some codema of both lower eye. lids. Palpitation and trembling still very troublesome. Cardiac action 96. Hands tremble wlien held out; tremors coarse and irregular. No perspirations. No exophthalmos or enlargement of the thyroid.

CASE 15. Palpitation, trembling, cramps, flushings, and sweats - Ruth L_, aged thirty, single, cook, came on Sept. $30 t \mathrm{l}_{\mathrm{l}}$, 1889, suffering from palpitation, attacks of trembling, and pain at the chest. There were well-marked tremors of the bands when extended. She was subject to cramps in the legs. The carliac action was rapid. The pulse was taken frequently, and varied between 92 and 120. Thère was no exophthalmos, and no thyroid enlargement. The hair was thin, and was coming out very much. She was subject to flushing, heats, and sweating. She said she had never been well since she was ten years old, but her present trouble had existed for about twelve months. The catamenia were irregular. she was irritable. Her legs swelled towards evening. Eight years ago she had been very much frightened by a strange man running after her.

\section{"THE LIVING EARTH."}

ABSTRACT OF ADDRESS TO SECTION I. OF THE SANITARY CONGRESS HELD AT BRIGHTON.

BY GEORGE VIVIAN POORE, M.D., F.R.C.P., PHYSICIAN TO UNIVERSITY COLLEGE HOSPITAL; PLOFESSOR OF CLINICAL MEDICINE AND MEDICAL JURISPRLDENCE, WNIERSITY COLLEGE, LONDON.

SANITATION in large cities is, at the best, a makeshift, and no bigh level of health is attainable in a place where the cbief object of hygienists seems to be to enable persons to live as densely packed as possible. This prelude is necessary, because the remarks which I am about to make are addressed mainly to persons who live in the country, and who enjoy the luxury of elbow-room, and I trust that what I am about to say will make them hesitate before they hastily copy the sanitary methcds of the town, and heedlessly hegin to fcster overcrowding, the bane of all sanitary and social virtue.

It has long been recognised by agriculturists that the upper stratum of the soil differs from that immediately below it in fertility; and in treatises on gardening (notably in that admirable work written by William Cobbett nearly seventy years since) the warning is invariably given to be careful, in trenching, not to bury the top spit of soil beneath the lower spit, because the top spit is by far the most fertile. The fertility in this case was supposed to be due to prolonged exposure to air, and the lower stratum of soil, if brought to the surface, would only become fertile after a considerable interval. It is interesting to observe that, althouch these early writers were unacquainted with the whole truth, they had grasped the most important fact, and their practice was sound. This is often the case, and I feel sure that we act rashly when we hastily abandon the custom of centuries because some new fact dazzles us and distorts our vision. The black vegetable mould which lies upon the surface of the earth is largely composed of organic matter, which is not to be woudered at, seeing that every organised thing, whether animal or vegetable, which inhabits this globe falls when dead upon the earth, and becomes incorporated witl it. This black vegetable mould is largely composed of excrement, for not only is the excrement of the larger animals being constantly added to it, but this and the varied organic débris which compose it pass repeatedly, probably, through the bodies of animals which inhabit the eartb, and especially of earthworms. Darwin, in his book on "Vegetable Monld and Earthworms," has forcibly drawn attention to the enormous amount of work which worms perform in the aggregate: how they disintegrate the soil; how they riddle it with burrows, which admit air to the deeper recesses of the soil ; how their castings, which are inces. santly being thrown off', tend to level inequalities, and gradnally to bury stones or whatever dead inorganic matter is incapable of solution, digestion, or disintegration. Earth worms are found almost everywhere, and they are probably the nost important of the animals which live in the soil but I need scarcely say that there are many others, and every. one who has a garden must recognise the fact that gardening is only carred out at an enormous sacrifice to animal life, for with every thrust of the spade into rich garden mould a deathblow is dealt to many of its inhabitants. The disintegration and aeration of the soil, which is effected by the quiet tillage of the earth-dwellers, is of the greatest. importance to the agriculturist, for it is hardly conceivable. that the delicate rootlets of plants could grow and extend unless the soil had been softened and pounded by the digestive. fluids and the gizzards of the earthworms and theirneighbours. Although the amount of cuimal life in the earth is considerable, it is nothing compared with the richness of the soil in the lower forms of vegetable life. The dead and excremental matter becomes the food of saprophytic fungi, which abound in the soil to a very great extent. This must be the case, for we know that saprophytes and their allies abound everywhere, and, as the surface of the earth is the common reservoir of all forms of life, it follows that these low vegetable microbes must be more abundant in the earth than elsewhere, and more abundant at the surface than deeper down.

In Watson Cheyne's editions of Flïgge's work on Micro. organisms ${ }^{1}$ this is clearly stated : "Enormous numbers of bacteria have always been found in the soil by the most various observers. Infusions made from manured field and garden earth, even though diluted 100 times. still contain thousands of bacteria in every drop, and the ordinary soil of streets and courts also shows the presence of large numbers. Bacilli are present in much the largest numbers; but in the most superficial lavers and in moist ground there are also numerous forms of micrococci." These micro-organisms of the soi are very active in producing changes in organic matter added to the soil. These changes are usually in the direction of oxidation; occasionally the change is one of reduction. One thing is certain, that if the soil be sterilised by heat or other neans, it is no longer capable of producing any chemical change in organic matter. This seems to me to be a fact of prime importance to the sanitarian. The oxidation and nitrification of organic matter in the soil is a biological question, pure and simple. It is an effect produced by the living earth; a process analogons to fermentation, which Cobbett seems to have appreciated. Whether the nitrifying process which takes place in the soil is due to one or to many varieties of microbe is doubtful, but the latter supposition is probably correct, and experiments seem rather to point to the con. clusion that, riven favourable conditions- the free admission of air to a soll which is not unduly moistened-nitrification. will go on. It has been conclusively shown by Flügge, Koch, and others that the microbes are most abundant ir the superficial layers of the soil, and that they tend to disappear in the deeper layers. They are practically absent in the deeper layers, unless the earth has been deeply stirred or trenched, or unless sewer or cesspoo: has conducted filth to the deeper layers without toushing the superficial ones. "Numerous filtration experiments on a large and small scale, have shown most distinctly that a layer of earth, half to one metre in thickness, is an excellent filter for bacteria, and hence the puritication of fluids from bacteria must be still more complete in cultivated, and especially in clay soil, and where the fluid moves with extreme slowness. Further, it has been repeatedly shown that wells which are well protected against contamination with bacteria from the surface and from the sides of the well furnish a water almost entirely. free from bacteria ; that, further, wells of water containing bacteria become the purer the more water is pumped out and the niore cround water comes in from the deeper layers of the soil." "The vegetahle living mould on the surface of the earth is in, short, a filter of the most perfect kind. It is very rich in saprophytic bacteria, whereas the subsoil at a depth varying from three to six feet is barren of bacteria, as well as of other kinds of life. The subsoil is nineral, inorganic, and dead ; the mould upon the surface is organic. and teems with life. Anything which is tarown upon the surface of the ground soon disappears. This is especially 
the case with water. The absorbing power of soil for water waries according to its mineral constitution. Loose sand and chalk absorb water very readily, and clay less readily, but the absorbing power of vegetable mould, or "humus," as it has been called, is infinitely greater. Humus is said to be able to absorb fron 40 to 60 per cent. of water, and to hold it wery tenaciously. This is from two to three times as much as the most porous dead mineral soil is capable of absorbing. The tenacity with which mould retains water is due to the fact that the water is absorbed into the interior of millions .of vegetable cells, and is not merely held by capillary attraction in the interstices between small mineral particles. It ris the swelling of individual cells which forms so effectual a barrier to the passage of bacteria. Not only water, but keverything else, when thrown upon the soil, disappears sooner or later. Such things as pieces of wood or leatherabout the toughest of organic material-become softened and permeated by fungoid growth, and finally crumble away. In some parts of the country rags of all kinds are largely ased for manure. Through the autumn and winter these may be seen lying on the surface, but when in spring the villing of the land goes forward and the fermentation of the soil commences the coarsest of these rags disappear. If wood, leather, and rags disappear, leaves and animal excrement disappear, as we all know, far more readily. "The disintegration is forwarded by birds, insects, worms, and their allies, and what was the excrement of a large animal becomes, as it were, the excrement of many small anes, until finally, by the action of saprophytic fungi, these organic matters become fertile "humus," which is the only permanent source of wealth in any country, the source whence we derive all the materials for our food and clothing.

The question whether among the bacteria which are found in the soil some may not be liurtful to mankind is of great interest and importance. If disease-causing organisms find their way into the soil, may they not multiply or at least continue to live, and then prove a 1anger to health? There can be no doubt that pathogenic organisms do exist in the soil, but their power for harm would seem to be practically very small indeed; and to regard the soil as dangerous because some pathogenic organisms may lurk in it would be about as rational as it would be to condemn veretable food becuuse of the occasional dangers of hernlock, aconite, or the deadly nightshade. It seems to be a fact that the great doctrine of "the survival of the fittest" holds good for microbes in the soil, as for all other organised things every where; and that organisms which flourish in the human borly languish and cease to multiply in the soil, where the conditions are un suited for their multiplication or even for their survival. They get overgrown by saprophytic microbes, and even iif they do not die, the risk of their finding their way iato the ground water is practically nil, for we have seen that humus is the best of filters. That the under strata of the soil are a very inefficient barrier against filth contamination bas been demonstrated in all our large towns, and especially in London. In that ity the lower rooms of the houses are almost universally below the level of the street, and the house drains leave the house at the lowest point to reach the sewer at a lower level still. In London, a city renowned for its innumerable "wells, we have had to close every one of them, and as the excessive dirtiness of the air makes rain-water not available for domestic purposes, we have become absolutely dependent upon the water companies, and it is only quite recently that the public has become alive to the fact that the causes which poisoned the surface wells are equally poisoning the Thames and the Lea, and the other sources of London water. No thinking being can feel easy about the London water-supply, and it is to be hoped that some day the public mind will be roused to an appreciation of the fact that if we want pure water we must nake some serious :attempt not to foul our wells and strearns. I am convinced that in our sanitary arrangements we have not sufficient]y - distinguished between the living mould of the surface and the dead earth of the subsoil. The living mould is our only efficient scavenger, which tbrives and grows fat upon every kind of organic refuse; our only efficient filter, a filter which swells and offers an impassable barrier to infective particles, a filter which afforks a sure protection to our surface wells. When we perforate the living humus with a pipe and take our dirty water to the subsoil, we, as it were, prick a hole in our filter, and every chemist knows wrat that means.
In order to keep the soil heal why, to keep up its appetite for dirt and its power of digestion, the only thing necessary is tillage. Well-cultivated soil, which is compelled to produce good crops, has never yet been convicted of causing any danger to health. Sanitation is purely an agricultural question, and in the country, where every cottage has, or should have, its patch of garden, there ought to be no difficulty in the daily removal of refuse from the house, and in applying it to agricultural purposes, without any risk of contaminating the water-supply. Given the patch of garden, the only thing necessary to bring about this, the only complete form of sanitation, is the will to do it --the will, that is, to do a profit to one's self without the possibility of darnaging one's neighbour. This, unfortunately, is rarely forthcoming, in spite of the Christian religion and the Education Act, and we go on, even in country places, polluting our streams and wells, with our minds agitated, as well they may be, as to when our water will become too poisonous to drink, and where we shall turn for a pure supply in the future. Sanitation is a purely agricultural and biological question; it is not an engineering question, and it is not a chemical question; and the more of engineering and chemistry we apply to sanitation, the more difficult is the purifying agriculture. This at least has been the practical result in this country.

The only engineering implements which the cottager with a bit of garden requires for his sanitation are a wateringpot and a spade, and if his garden be an allotment away from the cottage, a wheelbarrow may become necessary. The cottager, to whom the produce of his bit of land is a matter of consequence, will endeavour to fertilise as much land as possible with the organic refuse at his disposal; and as long as this endeavour is made there need be no fear of failure, either from the agricultural or sanitary point of view. When, however, an engineer, by means of water under pressure, has collected the organic refuse of a province at one spot, has diluted it a thousandfold, and endeavours to submit it to a mock purification by means of the least amount of land possible, failure is inevitable, both in the a.oricultural and sanitary sense. It was in 1848 that the advice to "drain" was tendered with a light heart by the pioneers of modern sanitation, who thought it would be an easy thing to purify the sewage and make a profit from it. The Thames, the Liffey, the Clyde, the Mersey, and the Irwell are a standing testimony to the failure of these great engineering schemes, and I wonld remind you that the last engineering scheme put forward with regard to the sewage of London-viz., to convey it all to the Essex coast and cast it into the sea-is not only a most lame and impotent conclusion, quite unanticipated by the pioneers of ' 48 , but it is an experiment which, like our previous experimente, may be productive of unforeseen results. The panacea for all sanitary ills has been and still is "drainage," and the only scavenger that is in favour is water, notwithstanding the fact that sanitation by water has for its main characteristic "incompleteness." The work is begun and never finished. Our houses are flushed, but we pay for it by fouling every natural source of pure water, whether river or surface well. If there come an outbreak of typhoid, we, as often as not, find the "drains" are to blame ; but, as a matter of fact, we prescribe " more drains" as the remedy. I have asked my friend and former pupil, Mr. F. W. Wells, M.B., to go through the official reports which have emanated from Whitehall since 1856 , and make an abstract of the chief outbreaks of typhoid fever in this country which have been reported by the medical officers of the Privy Council and the Local Govern. ment Board. This Mr. Wells has done in a most painstaking and methodical manner, and the tables which he has constructed form an appendix to this paper which is well worthy of perusal. If you will scan this appendix, you will find that there is one factor common to all these outbreaks-viz, the mixing of excremental matters with water. This mixture generally leaks to the well or rivulet, or waterpipe which supplies the drinking water (which water has not unfrequently been sold under the name of milk), and the result is an outbreak of typhoid. Or the mixture putrefies in a cesspool or sewer, and the gases finding an entrance to our bouses cause an outbreak of typhoid. There is no doubt whatever that whenever excrement is mixed with water we are in danger of typhoid. Typhoid was not recognised in this country until the watercloset became common. We doubtless manufactured typhoid in a retail fashion in old days, but with the 
invention of the watercloset we unconsciously embarked in a wholesale business. We soon recognised that the watercloset poisoned all sources of water. We have had to ro far afield for drinking water, and the result has been that as we left off consuming the springs which we have wilfully poisoned the amount of typhoid has somewhat abateil. When the inore remote sources of water get poisoned in their turn-as with onr increasing population and our methods of aanitation they inevitably must-the present comparative abatement must, one would fear, cease.

It is comparatively recently that we have learnt to recognise the dangers which result from the putrefaction of a mixture of excrement and water in a sewer or cesspool. The ingenuity of sanitary engineers has been exercised to save us from these dangers, and they have given us what they are pleased to call self-cleansing sewers, innumerable forms of trap, endless methods of ventilation, and disconnexion on scientific lines, until the medical officer of health is expected to have at his fingers' ends all the knowledge of a patent agent and a plumber's foreman. If apparatus never wore out, if ventilators never got stopped up, if traps never got unsealed by leakage, evaporation, or other cause, one might feel secure against the enemy which is ever at our gates, provided the study of bacteriology did not lead us to recognise that a few feet of filthy pipe may be as dangerous as a mile, and that a trap may possibly serve, especially in hot weather and when the family is away, as a most efficient cultivating chamber. It is commonly urged by those who defend our present methods of sanitation that, as we must of necessity provide some channel for the escape of slops from our houses, it is false economy not to make these channels carry every thing; or, in other words, that, as sewers are a necessity, there is no harm in making them a bigger nuisance than they necessarily must be. I confess I am unable to follow this argument and I would submit some reasons why every effirt should be made to keep excremental matters out of the sewers. 1. Excrement is the only in gredient of sewage against which dangerous infective properties have been proved again and again. It is the ingredient which, when mixed with water, finds its way to our drinking water and causes typhoid and cholera. Sewage without excremental matters is doubtless offensive, and is probably unwholesome in many ways ; but it stands in the position of a "suspect," rather than that of a habitual criminal against whom no end of previous convictions have been proved. 2 . If excremental matters were stopped out of our house drains, we could in country places often have recourse to the old practice of allowing our household slops to run in open gutters, concerning the ventilation of which there could be no doubt, and the gutters might be subjected to the wholesome discipline of a broom and the purifying intluences of sunlight and drying winds. 3. If ex cremental matters be stopped out of the house drains, the total volume of sewage to be dealt with would be diminished by at least one-fifth, and this surely is a great gain. We should deprive the sewage of just those ingredients which are most troublesome to the sewage farmer by clogging the pores of the ground. and we should leave the sewage verv "thin" and admirably suited for downward filtration. I seems to be an acknowledged fact that, for the application of sewage to the land, the more watery it is and the more completely solid matters are strained ont of it, the simpler and more satisfactory the processes become. 4. Another class of objections which has been made to the exclusion of solid excrement from house drains has reference to the so-called "manurial value" of sewage and its constituents. It is said that excreta witbout the total urine are of low manurial value, and that the stopping of excreta out of the sewers lowers the manurial value of the sewage. "Manurial value" is a term used by chemists to express the amount of nitrogen that may be present. Now do not doubt the ability of chemists to make a quantitative estimation of nitrogen, nor their power of is forming farmers of the extent to which they may or may not have been cheated when they purchase artificial manures. I would humbly suggest, however, that the real practical manurial value depends not only upon the amount of plant-food present, but also upon whether the plant.food is present in a form in which it can be digested and exhaustively utilised by the plant. For the latter information, which is of the highest importance, I would sooner apply to a prastical farmer or gardener than to a chemist. A chemist, for instance, who had regard to his analyses and nothing else, might tell us that nut-shells liad a certain dietetic value; buc ordinary men and monkeys know better than that. He might tell us that gin was richer in certain dietetic ingredients thas ginger beer, but we know that ginger beer is the better article of diet. Again, guano has a far higher manurial value than " rich garden mould," such as is got by mixing earth with organic refuse; but if we do not dilute our guano to the same level, so to say, as our rich garden mould, we may kill our plants. To declare that rich garrlen mould is of low manurial value is absurd, because we know that in it plants of all kinds reach the highest development which is attainable. Farmers and market gardeners will tell you that artificial manures have "got no bottom in them," that their use is, so to say, a speculation; and if climatic conditions are unfavourab?e when the artificials are applied, the money spent on them is lost for ever. With organic refuse, however, the case is entirely different, and the effect of the application of organic matter, especially of human origin, to the soil, is plainly discernible for three or four years. Solid organic matter cannot be washed away; it nitrifies slowly, and doles out the nitrates to the roots of the plants in proportion as they are needed.

I wish to say emphatically that the manurial value of human excrement is enormous, and that it produces all kinds of fruits, flowers, and vegetables in the highest per fection. I speak from a practical experience of nine years and my belief is that soil cannot be made more fertile than by mixing it with solid excremental matter. It is quite true, no doubt, that the manurial value of urine is very great, but being fluid it is not so easily retained at the spct where the agriculturist wants it; and we know that when fresh and undiluted it is very dangerous to herbage. The fact is that plants absorb their nutriment from very dilute solutions; and it has been found that a fluid containing abnut 2 per cent. of solids is the optimum for plant culture. Ordinary urine, therefore, which contains 4 pes cent. is twenty times too strong; but if it be applied to the soil in its state of optimum dilution, much of the liquid will necessarily soak out of the reach of the roots. Manurial value is a practical matter rather than a chemical problem. and I have no doubt whatever that those who assert the manurial value of earth-closet manure to be low ar making a very serious practical mistake; and I have no douht that arguments based on the theoretical manuria value of sewage as a whole, or of its several ingredients, are worthless in helping us to decide whether it be advisable or otherwise to keep solid matters out of the drains. What use is there in discussing the "manurial value" of sewage in the face of the deliberate declaration of that eminent agriculturist, $\mathrm{Mr}$. Clare Sewell Read, maile a few months since in the Journal of the Royul Agriculturcl Society? "Sewage," says Mr Read, "has come to be regarded by all sensible people simply as a nuisance to be got rid of" And he goes on to state that, owing to the unmanageable quan tiries of water which have to be dealt with, sewage is ruinous to all grain crops and all other farm crops except rye grass. The composition of sewage as it flows from town is so doubtful, and must be so variable, that no sencible man would let it run over his farm. Chemicals and antiseptics are very abundant at the present day, and they are very largely used to lessen the dangers which are inherent in our present system of sanitation. Antiseptics, however, which stop the growth of putrefactive microbes, also check the growth of nitrifying organisms, and are deadly poison to plants. All town sewage is liable to contain dangerous chemicals, which must render the "manurial value" a very minus quantity, the presence of nitrogen notwithstanding As it is idle to discuss the theoretical manurial value of a practical nuisance, which no sane farmer would take as a gift, it is imperative for us to discover means, if possible by which those ingredients of sewage which have great en riching power for the soil may be saved for the benefit of the cultivator and consumer.

From every point of view-scientific, sanitary, moral, economic-I feel strongly that dwellers in the country should take warning by the towns. They should revert to the cleanly and decent habits of our forefathers, and keep the sanitary offices away from the main structure of the house, and not, as is the filthy custom of the present day, bring them almost into the bedrooms. They should keep solid matters out of the house drains, and see that they are decently buried in the living earth every day, and they should replace the drains by gutters and filter all the bonse- 
hold slops by applying them to the top of a different piece of cultivated ground every day. Whether an ordinary watering-pot or a tank upon wheels drawn by a horse be necessary for accomplishing this latter object will depend upon the size of the establishment; but only those who hare systematically pursued this plan, as I have done, can know the vigour which is imparted to hedge-rows, shrubberies, fruit trees, or forest trees, by a tolerably frequent dose of household slops. There is no difficnlty in doing this, provided the will be present-the will, that is, to combine your duty towards your neighbour with an act which is profitable to yourself.

I am addressing myself to dwellers in the country, but I should like to say to town dwellers that complete sanitation is impossible, unless cultivated land be brought into tolerably close relationship with the dwelling. At present our sanitary arrangements are magnificently begun and seldom completed, and while we almost uniformly leave a most dangerous loose end to our sanitary measures, we shut our eyes to it and blow the trumpet of self-satisfaction as if the sanitary millennium had begun. The Allotment Act, as affording an outlet for organic refuse, ought not to be without its effect upon sanitation, and it is to be hoped that the masses will some day wake up to the great importance, from the moral and sanitary standpoint, of providing every $d$ welling with an adequate outlet. As things go at present, I have very little doubt that the agricultural labourer with his cottage and garden and $12 \mathrm{~s}$. a week is infinitely better off than the town artisan on $25 \mathrm{~s}$., who pays dearly for pigging it in overcrowded rooms, in which a cleanly and decent existence is impossible. have been reading the last volume of our Transactions, and in it I find a very interesting paper by Dr. Sykes, who quotes Dr. Corfield, who, in his turn, is quoting Sir Henry Acland, to the effect that the disappearance of the great cities of antiquity was due to pestilence rather than war. We must all admit the possibility of such an assumption, and certainly no one can ponder upon the disappearance of Egyptian, Babylonian, Assyrian, Greek, and Roman civilisation without speculating upon the cause, and without applying the lesson to ourselves and asking ourselves how much longer is our British civilisation to continue? Nationalities seem as mortal as the individuals who compose them. If great nations are destroyed by neglect of sanitary laws, and if prolonged national life is indicative of sound sanitary measures, there is at least one race upon the globe which is worthy of profound study by all who concern themselves with public health. This race is the Chinese, who have seen all the great nations of antiquity in and out, who were probably a great people in the days of Moses and before, and whose thrifty myriads are even now successfully contending with the Anglo-Saxon race in America and Australasia. The Chinese, as is well known, have had to contend with national calamities of a most stupendous kind. In our own days we hear of floods and famines which claim their millions of victims, and yet the race continues to increase in such a way and to overflow its natural boundaries to such an extent that it is certain, even without the exact returns of a registrar.general, that the birth-rate must very considerably exceed the death-rate, and must have done so in an average way during the three or four thousand years that the Chinese nation has existed. I think there is no doubt that, unless we mend our ways, the Chinese will see us out, as they have seen the other great nations of the world out, and the reason, I believe, is obvious. The Chinese are the most thrifty nation in the world. In China nothing is wasted, and all organic refuse is ultimately returned to the soil. Agriculture is in China a sacred duty, and the Chinese have got a firm grasp of the elementary principle that if the fertility of the earth is to be maintained we must constantly replenish it.

The question of our duty to the soil is fundamental in sanitary matters. If we starve the soil and turn our fertilising materials into the sea, we may rid ourselves (though this is doubtful) of filth diseases for a time; but it is by no means doubtful that we shall ultimately replace filth diseases by those diseases that are bred of starvation. How soon this will happen no one can say, but that it will happen eventually seems to me as certain as is the axiom, "ex nibilo nihil fit." Do not let us commit the great blunder when dealing with this national question of forgetting that the life of a nation ought to be measured by centuries. Do not let us make a suicidal use of a paltry fifty years' statistics, and because the figures of the last decennium happen to be favourable conclude therefrom that all our sanitary principles are right. The Chinese principle of returning all organic refuse to the soil is, there can be no doubt, absolutely sound. The Chinese details may be filthy and susceptible of improve. ment. In this country the details of our domestic sanitation are refined, elegant, and ingenious. It is the principle subserved by these details which I believe to be absolutely rotten. The main problem of sanitation is to cleanse the dwelling day by day, without fostering starvation. This can only be done by returning all organic refuse to the soil, and the perfecting of the details by which this duty is to be done is the most important work of the modern sanitarian. This question has an immediate personal interest for all who derive their income from the soil. I feel sure that the clergy would do well to enforce by example as well as by precept the old injunction, to "replenish the earth and subdue it." If they do not they must expect to go without their tithes. Improvement in this direction is only to be attained by rousing the public conscience. So soon as the majority of individuals is impressed with the fact that it is wicked to foul our streams and starve the soil, and that our individual responsibility does not end, even though the fouling and starving be done by a "board," so much the better will it be for the public health and national wealth. Parliament has compelled us to hand over our responsibilities to public authorities, with the consequence that the individual has lost his liberty and independence, and is drifting into a condition of sanitary imbecility. Let us not forget that the present state of our rivers is the direct result of Acts of Parliament. Let us not forget that Parliament, which wasted its time and our money in passing that most inoperative of all Acts, the "Rivers' Pollution Act," scavenges its own palace direct into the Thames; as though Imperial Parliament could hand over its responsibilities to a local board! It is hardly credible that such a condition of things could exist outside the libretto of a comic opera. A respect for the purity of water should be enforced in our Board schools and churches; and that powerful party in the State-I mean the ternperance party-would do well to devote some of its energies towards ensuring that the beverage which it champions should be in all places a safe one to drink. As it is, one has only to walk about the country to see that our streams and rivulets are universally regarded as receptacles for rubbish and impurities of every kind. This question, I must reiterate, in conclusion, is a national one of the first importance. A nation that fouls its streams and starves its soil is in danger of poisoning and inanition. A nation which imports a great part of its food and a great part of its manure, and systematically and by Act of Parliament throws all its organic refuse into the sea, is obviously living on its capital. Our capital just now is undoubtedly considerable, but we are in a fair way to run through it; and when we have done so, who can forecast the tuture?

\section{SURGERY OF THE LATERAL VENTRICLES OF THE BRAIN. ${ }^{1}$}

\section{BY W. W. K E E N,}

PROFESSOR OF SURGERY IY THE JEFFERSON MEDICAL COLLLGE, PHILIDELPIIA, PA.

AFTER alluding to the fact that puncture of the brain for the relief of hydrocephalus dates back to 1744 , in the case of Dean Swift, Dr. Keen pointed out that the former operations were done through the anterior fontanelle, and not by trephining. In 1881 Wernicke tis st proposed to trephine and puncture the lateral ventricles. This proposition was enforced by Zenner of Cincinnati in 1886. On Nov. 7th, 1888,2 Dr. Keen read a paper before the College of Physicians of Philadelphia, in which, in ignorance of these earlier propositions, he proposed to trephine, puncture, and drain the lateral ventricles. He was led to this by a case of exploratory trephining for supposed abscess of the temporo-sphenoidal iobe. The necropsy showed that there was distension of the lateral ventricle in consequence of tubercular menin-

1 Résumé of a paper read before the Tenth International Nedica 1 Resumé of a paper read before the Tenth Internationg
Congress, Berlin. 